\title{
PREAMBULO PARA UNA LECTURA COMPARADA DE UN POEMA DE HUIDOBRO
}

El viernes 2 de abril de 1926 -año de uno de sus regresos a Chile- Vicente Huidobro publicó en La Nación, diario de Santiago, «Pasión y muerte» (y no "Pasión, pasión y muerte», como lo tituló luego). El poema compartió la primera página del periódico con la traducción de un artículo, «El sepulcro de Cristo», y otra de «Por las tierras de Judea», de Eça de Queiroz. El carácter pareado de la estrofa de versos largos y rimas (pobres) no mereció la atención del diagramador, quien despedazó el poema repartiéndolo entre tres columnas del mismo ancho.

Vicente Huidobro acababa de publicar en Chile Vientos contrarios, un libro de niño terrible destinado a épater «a los caballeros que pastan en los potreros chilenos», y el poema prolonga esa actitud desafiante, en el modo de una alocución místico-erótica, de una oración pagana. El poeta desterró el texto de sus libros posteriores, induciendo a sus primeros antólogos y admiradores a la precaución. Eduardo Anguita, en el prólogo de su antología, optó por relativizar el elogio: «Este poema no pertenece a ningún libro... lo incluimos más que nada por significar en Chile un tono poético absolutamente inusual». ¿Sabía que fuera de Chile no era así?

No puede haberlo ignorado en cambio muchos años más tarde Braulio Arenas, cuando pasó por «Pasión, pasión y muerte» la brocha gorda del elogio en las Obras completas de Vicente Huidobro editadas por Zig-Zag: «Mientras toda su poesía anterior - reza el panegírico prologal - refleja una inmediata preocupación estética, en esta obra LA REALIDAD toca la ventana y penetra por ella convertida en un furioso vendaval. El alma entera queda volcada, esa alma que había vivido para los rigores de la poesía y no para los rigores del mundo».

Hace algunos años, y todavía muchas veces ahora mismo, el mejor elogio que se le dispensa a la poesía - reconocidamente irrealista- es el reconocimiento de que también ella es capaz de constituirse en el reflejo artístico de lo real. Marthe Robert nos ha enseñado que el inte- 
rés de la novela por imitar la realidad y asumirla como una carga responde a la mala conciencia de los prestidigitadores de lo real, que se sienten culpables de la «bien conocida complicidad del placer y la mentira». Los poetas, que parecían libres de ese problema, también lo padecen. Salvo en casos de excepción como el de Lezama Lima, que al final de su vida perseveraba en las bondades de lo imaginario: «sólo la poesía logra destruir la antítesis realidad e irrealidad formando una esperada médula de saúco».

Vuelvo a Huidobro. Lo que toca a la ventana de «Pasión, pasión y muerte" es la realidad, pero de la poesía. Y lo que entra en la escritura de Huidobro, en el modo de las relaciones intertextuales, son dos poemas gemelos, claves de la poética de vanguardia: «Pascuas en Nueva York» -Les Pâques à New York (abril 1912)_, de Blaise Cendrars, que apareció en octubre de ese año en Les Hommes Nouveaux; y «Zone», de Guillaume Apollinaire, publicado en Les Soirées de Paris en diciembre del mismo 1912. Hizo bien, pues, el poeta Anguita en advertir que el tono del poema era inusual, pero sólo en Chile. Que Huidobro no incluyera luego en sus libros un texto como ése me parece que se debe menos a un criterio selectivo que a una táctica defensiva. Como el propio Cendrars, a quien se asemeja más que a Apollinaire en tanto autor inscrito de sus textos, Huidobro postulaba una suerte de originalidad absoluta para la poesía, fundada siempre — contra lo que parece- en una determinada relación con la vida. Las doctrinas de Huidobro tuvieron como función el garantizar la unicidad del sujeto. Lo llamativo de su personalidad, la espontaneidad de quien para jugar cambia a su amaño las reglas del juego. Una literatura sin precedentes es una antiliteratura. Por todo lo cual podía correr el riesgo de ser acusado de plagio mientras no estuviera seguro de ser absuelto y celebrado por su habilidad de malabarista para la apropiación de lo ajeno. El rechazo por su parte del texto conlleva su reconocimiento de que en ese caso se sabía indefendiblemente plagiario.

Hago obviamente conjeturas. Las fundo primero en la categoría de originalidad que obsesiona a la poesía de vanguardia; segundo, al cuidado que Vicente Huidobro puso en producir el efecto de originalidad en sus textos más prevenidos (mediante el hábil escamoteo de las relaciones intertextuales y los presupuestos supuestamente teóricos de su praxis poética), y tercero, en la evidencia de la enajenación de «Pasión, pasión y muerte» a «Pascuas» y «Zona», de la que debió de estar consciente Huidobro. Hay hasta una diferencia cuantitativa: los 109 versos del texto de 1926 frente a los poemas largos del año 12. A la mala conciencia de la imitación quizá se deba el que «Pasión, pasión y muerte» responda 
a un proyecto menos ambicioso que el realizado por sus modelos de 1912.

En suma, la obra global de Huidobro presenta varias formas de la relación de texto a texto. Se ha empezado a ver esto en lo que respecta al Mio Cid Campeador. Creo que entre esas relaciones no figuran ni la parodia como mímesis crítica de un lenguaje ni la crítica que implica -por ejemplo, de Bertolt Brecht- el empleo de un lenguaje (idealismo) en el ámbito de otro (el de la compra y venta). Vicente Huidobro, en sus textos más avanzados desde su punto de vista, compite con antecesores inmediatos y con sus presuntos rivales -Pierre Reverdy y otros- en la novedad sorpresiva del producto-poema, rival de las novedades tecnológicas. Y lo hace homologando el arte (de la palabra) y la ciencia en una forma algo «ingenua» al optar por un lenguaje instrumental, una especie de esperanto. Pues lo que decía interesarle era el objeto creado, respecto del cual la lengua es una mera correa de transmisión.

La originalidad en este campo tecnológico es una instancia contradictoria. Lo más nuevo arranca de lo nuevo y lo absolutiza. La originalidad del último modelo y de la marca de fábrica. De aquí las que estimaba Pierre Reverdy características contradictorias de nuestra época: imperiosa necesidad de orientación común, dirección única, agrupamiento, generalización de hallazgos personales, seguido de un extremo amor propio de autor. Individualismo (marca de fábrica) absoluto, una sed excesiva de originalidad, etc. La relación de la vanguardia con el mercado no sólo da cuenta del proceso de recuperación para el museo de las transgresiones vanguardistas. También una vanguardia (eufórica la llamó muy bien Saúl Yurkievich) produce para el mercado o instaura en el campo cultural los mecanismos de la producción y consumo de una sociedad consumista. En este sentido se está con el mundo y no contra él como en el romanticismo. Pero la producción artística paga las consecuencias alienándose, como ocurrió parcialmente en el caso de Huidobro, al anacronismo de la novedad. O a la mala conciencia del plagio.

ENRIQUE LIHN

Universidad de Chile. 
